\title{
Design and development of weeding-cum-earthing-up equipment
}

\author{
Sunny Raina and J.P. Singh
}

Received : 20.06.2018; Revised : 14.08.2018; Accepted : 30.08.2018

See end of the Paper for authors' affiliation

Correspondence to :

\section{J.P. Singh}

Division of Agricultural Engineering, Sher-e-Kashmir University of Agriculture Science and Technology, Jammu (J\&K) India Email : jai12123@rediffmail. com
- ABSTRACT : Every year in India, an average of $1980 \mathrm{Cr}$ of rupees is wasted due to weeds. Our country faces the total loss of 33 per cent of its economy from weeds. Shrinking farm lands, acute labour shortage, decreasing income per acre of cultivation, and economic frustration are some of the key factors hurting a farmer's confidence in continuing farming. Weeding control is done by: mechanical weeding, thermal weeding: flaming, biological control, chemical control and by farming pattern. It has always been a problem to successfully and completely remove weeds and other innocuous plants and also earthing-up the crop. In order to overcome these problems weedingcum-earthing-up equipment was developed. This work involved the design and construction of low cost weeding-cum-earthing-up equipment, which consists of two main units viz., first weeding unit and second soil cutting and earthing-up unit. A serrated blade and two discs were selected for weeding and earthing-up operations, respectively. The weeding efficiency and cutting width of developed equipment was found 90.7 per cent and $35 \mathrm{~cm}$, respectively.

- KEY WORDS : Weeding, Earthing-up, Working width, Weeding efficiency

- HOW TO CITE THIS PAPER : Raina, Sunny and Singh, J.P. (2018). Design and development of weeding-cum-earthing-up equipment. Internat. J. Agric. Engg., 11(2) : 324-327, DOI: 10.15740/ HAS/IJAE/11.2/324-327. Copyright@ 2018: Hind Agri-Horticultural Society. 